\title{
PERANCANGAN MODEL ENTERPRISE ARCHITECTURE MENGGUNAKAN TOGAF ADM VERSI 9.2 PADA APLIKASI LAYANAN ONLINE PELANGGAN (Studi Kasus: PT. PLN Persero Unit Induk Wilayah Kalimantan Barat)
}

\author{
${ }^{[1]}$ Indah Zulfah Alqadrie, ${ }^{[2]}$ Ilhamsyah, ${ }^{[3]}$ Nurul Mutiah \\ ${ }^{[1][2][3]}$ Jurusan Sistem Informasi; Fakultas MIPA Universitas Tanjungpura; \\ Jalan Prof. Dr. H. Hadari Nawawi, Pontianak \\ Telp / Fax: (0561) 577963 \\ e-mail: ${ }^{[1]}$ indahalqadrie@ student.untan.ac.id, ${ }^{[2]}$ ilhamsyah@ @isfo.untan.ac.id, \\ ${ }^{[3]}$ nurul@sisfo.untan.ac.id
}

\begin{abstract}
Abstrak
Penggunaan aplikasi layanan pelanggan PT. PLN yang dapat diakses pelanggan dengan mudah dan cepat memiliki fitur-fitur yang dapat membantu dalam mengatasi masalah tenaga listrik. Untuk dapat meningkatkan penggunaan aplikasi layanan pelanggan itu perlu adanya perancangan enterprise architecture yang dapat mengintegrasikan bisnis dan teknologi informasi. Permasalahan yang ada pada aplikasi layanan online pelanggan belum terdapat fitur pelacakan pengaduan listrik yang dapat diakses pelanggan didalam aplikasi dan penggunaan teknologi big data agar proses bisnis dan teknologi informasi dapat selaras sesuai dengan tujuan dalam perancangan enterprise architecture. Dalam perancangan enterprise architecture terlebih dahulu menentukan visi arsitektur yang akan dibuat pada perancangan baseline dan target architecture. Setelah dibuat rancangan baseline dan target architecture kemudian dilakukan analisis gap di fase business architecture sampai dengan technology architecture. Setelah semua rancangan setiap fase dibuat, kemudian dilakukan pengujian kualitas rancangan enterprise architecture menggunakan metode enterprise architecture scorecard dengan memberikan kuesioner berupa pertanyaan-pertanyaan. Hasil pengujian dilakukan kepada Manager dan Asisten Manager Operasional Sistem dan Teknologi Informasi PT PLN. Dari hasil pengujian enterprise architecture mendapat nilai rata-rata 63,34\% berdasarkan perhitungan kuesioner menggunakan enterprise architecture scorecard. Hasil dari perancangan tersebut dapat terus ditingkat dengan melengkapi komponen yang kurang dalam melakukan perancangan enterprise architecture.
\end{abstract}

Kata Kunci-EA, TOGAF ADM, EA SCORECARD.

\section{PENDAHULUAN}

Teknologi informasi tidak bisa lepas dari hubungannya dengan proses bisnis dari suatu perusahaan, organisasi maupun instansi pemerintahan. Perusahaan maupun instansi harus mampu mengintegrasikan teknologi informasi atau aplikasi yang selaras dengan bisnisnya untuk meningkatkan keamanan, menghindari adanya duplikasi data dan analisa data yang akan digunakan perusahaan untuk membuat keputusan baru. Agar dapat bersaing tentunya perusahaan maupun organisasi harus memiliki rancangan blueprint enterprise architecture yang dapat membantu tercapainya strategi bisnis terintegrasi dengan teknologi informasi yang diinginkan untuk memaksimalkan dalam pelayanan pelanggan yang lebih efektif dan juga dapat meningkatkan value bisnis bagi perusahaan atau organisasi.

Enterprise architecture pada dasarnya merupakan strategi pemanfaatan teknologi informasi dan integrasi antara pengembangan bisnis dengan pengembangan teknologi informasi. Implementasi dari enterprise architecture dapat digunakan oleh perusahaan maupun organisasi, sebaiknya dalam membuat perancangan enterprise architecture harus mengadopsi sebuah metode atau framework yang dapat digunakan oleh perusahaan maupun organisasi [1].

Salah satu framework enterprise architecture yang dapat digunakan adalah TOGAF yang dikembangkan oleh The Open Group. Di dalam standar TOGAF ini terdapat 
metode yang dapat digunakan untuk merancang blueprint enterprise architecture yaitu TOGAF ADM. TOGAF ADM merupakan metode generik yang berisikan sekumpulan aktivitas yang digunakan dalam memodelkan pengembangan enterprise architecture [2].

PT. PLN Persero merupakan Badan Usaha Milik Negera (BUMN) yang menyediakan layanan tenaga listrik untuk menjangkau keseluruh wilayah Indonesia. PT. PLN memberikan layanan pelanggan secara online melalui aplikasi mobile yang dapat diakses pelanggan dengan mudah dan cepat yang memiliki fitur-fitur yang dapat membantu masyarakat. Namun aplikasi layanan pelanggan ini masih terdapat kekurangan antara lain belum memiliki fitur pelacakan dari layanan pengaduan pelanggan untuk mengetahui perkembangan dari pengaduan yang diajukan oleh pelanggan.

Maka dari itu dibutuhkan teknologi informasi selaras dengan bisnis PT. PLN yang dapat memaksimalkan proses pelacakan dari layanan pengaduan pelanggan, sehingga memudahkan pengguna dapat mengetahui pelaporan gangguan dengan cepat dan efisien. Selain itu, pada aplikasi layanan online pelanggan ini belum memiliki teknologi big data yang dapat menampung data dan menganalisa data dengan skala besar untuk kepentingan perusahaan.

\section{LANDASAN TEORI}

Didalam landasan teori terdapat dasar teori yang digunakan dalam penelitian dan tinjauan pustaka untuk menjadi pembanding dengan topik penelitian saat ini. Adapun dasar teori dan tinjauan pustaka yakni sebagai berikut.

\subsection{Dasar Teori}

\subsubsection{Enterprise Architecture}

Enterprise architecture merupakan salah satu cara mewujudkan gambaran umum tentang enterprise secara logis, utuh dan lengkap yang kemudian hasilnya meliputi arsitektur bisnis, arsitektur informasi, arsitektur aplikasi dan arsitektur teknologi. Implementasi dari enterprise architecture bisa digunakan untuk organisasi dan perusahaan, sebaiknya dapat menggunakan sebuah metode atau framework yang bisa digunakan dalam melakukan perancangan enterprise architecture tersebut [3]. Sehingga dengan adanya metode enterprise architecture tersebut diharapkan dapat mengelola sistem yang terintegrasi dan dapat menyelaraskan bisnis serta teknologi informasi yang akan di investasikan [4].

\subsubsection{Framework Enterprise Architecture}

Dalam melakukan perancangan enterprise architecture, harus adanya panduan, standar, kebijakan, dan aturan-aturan bisnis yang dapat menggambarkan lingkungan dari perusahaan atau instansi pemerintahan. Kegunaannya adalah untuk memaksimalkan peran dari enterprise architecture karena sebuah framework enterprise architecture memiliki model simbolis untuk mengidentifikasi dan menspesifikasikan berbagai fase-fase enterprise architecture. Di antara framework enterprise architecture yang paling banyak dan lazim digunakan dalam perusahaan maupun instansi pemerintahan adalah Zachman Framework, TOGAF, The Federal Enterprise Architecture Framework (FEAF), dan Gartner [5]. Berikut ini kriteria penilaian berdasarkan rating sebagai perbandingan diantara keempat framework yang dapat dilihat pada tabel 1 .

Tabel 1. Kriteria dan Rating Framework Enterprise Architecture [5]

\begin{tabular}{|l|c|c|c|c|}
\hline \multirow{2}{*}{ Kriteria } & \multicolumn{4}{c|}{ Rating } \\
\cline { 2 - 5 } & $\begin{array}{c}\text { Zachm } \\
\text { an }\end{array}$ & TOGAF & $\begin{array}{c}\text { FEA } \\
\text { F }\end{array}$ & Gartner \\
\hline $\begin{array}{l}\text { Kelengkapan } \\
\text { Taksonomi }\end{array}$ & 4 & 2 & 2 & 1 \\
\hline Kelengkapan Proses & 1 & 4 & 2 & 3 \\
\hline $\begin{array}{l}\text { Pedoman Model } \\
\text { Referensi }\end{array}$ & 1 & 3 & 4 & 1 \\
\hline Pedoman Practice & 1 & 2 & 2 & 4 \\
\hline Maturity Model & 1 & 1 & 3 & 2 \\
\hline Fokus Bisnis & 1 & 2 & 1 & 4 \\
\hline $\begin{array}{l}\text { Pedoman } \\
\text { kelola }\end{array}$ & 1 & 2 & 3 & 3 \\
\hline $\begin{array}{l}\text { Pedoman } \\
\text { Partitioning }\end{array}$ & 1 & 2 & 4 & 3 \\
\hline $\begin{array}{l}\text { Prescriptive } \\
\text { Catalog }\end{array}$ & 2 & 4 & 2 & 1 \\
\hline Vendor Neutrality & 2 & 4 & 3 & 1 \\
\hline $\begin{array}{l}\text { Ketersediaan } \\
\text { Informasi }\end{array}$ & 1 & 3 & 1 & 4 \\
\hline Time to Value & & & 2 \\
\hline
\end{tabular}

\subsubsection{The Open Group Architecture Framework - Architecture Development Method (TOGAF ADM) \\ TOGAF ADM merupakan metode yang} fleksibel yang dapat mengantifikasi dari berbagai macam pemodelan yang dapat digunakan dalam perancangan enterprise 
architecture, karena metode ini dapat disesuaikan dengan perubahan dan kebutuhan selama perancangan enterprise architecture [4]. Siklus fase di dalam TOGAF ADM dapat dilihat pada Gambar 1.

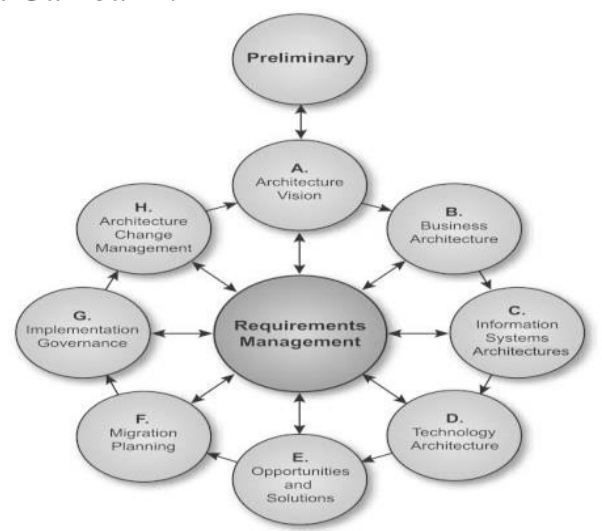

Gambar 1. Siklus fase TOGAF ADM Versi 9.2 [2]

Gambaran siklus TOGAF ADM dapat dijelaskan sebagai berikut:

1. Preliminary Phase, merupakan fase persiapan yang bertujuan untuk mendefinisikan perusahaan, mengidentifikasi driver dan elemen utama dari perusahaan, mendefinisikan requirement arsitektur, mendefinisikan prinsip arsitektur, menentukan kerangka kerangka kerja arsitektur yang digunakan.

2. Architecture Vision, merupakan fase untuk menetapkan ruang lingkup enterprise architecture, menentukan batasan dan visi arsitektur, mengidentifikasi stakeholder dan persetujun untuk pengembangan arsitektur untuk mencapai tujuan bisnis perusahaan.

3. Business Architecture, merupakan fase untuk mengembangkan arsitektur bisnis dengan membuat baseline dan target dari arsitektur bisnis dan membuat analisis gap.

4. Information System Architecture, merupakan fase untuk mengembangkan arsitektur sistem informasi terkait pada arsitektur data dan aplikasi yang akan digunakan dengan membuat baseline dan target dari arsitektur sistem informasi dan membuat analisis gap.

5. Technology Architecture, merupakan fase untuk mengembangkan arsitektur teknologi yang digunakan dengan membuat baseline dan target arsitektur serta membuat analisis gap.
6. Opportunities and Solution, pada fase ini menghasilkan roadmap arsitektur secara keseluruhan berdasarkan analisis gap lengkap dari phase $\mathrm{B}, \mathrm{C}$, dan $\mathrm{D}$ dan menentukan tambahan pendekatan yang diperlukan.

7. Migration Planning, pada fase ini merupakan finalisasi dari keseluruhan roadmap arsitektur dan rencana migrasi yang mendukung implementasi. Terdapat juga analisis biaya, manfaat dan resiko dari pengembangan enterprise architecture yang dibuat.

8. Implementation Governance, pada fase ini menyediakan pengawasan dari pengembangan arsitektur untuk implementasi dan memastikan implementasi tersebut sesuai.

9. Architecture Change Management, pada fase ini menyediakan pengawasan berkelanjutan dan manajemen perubahan untuk memastikan bahwa enterprise architecture dapat menanggapi kebutuhan perusahaan.

\subsubsection{Archimate}

Archimate adalah sebuah standar The Open Group yang merupakan bahasa pemodelan untuk enterprise architecture yang menyediakan sebuah instrumen untuk mendeskripsikan dan memvisualisasikan hubungan antar domain dengan cara yang jelas. Konsep inti dari Archimate ini terdiri tiga elemen utama yaitu: elemen struktur aktif, elemen tindakan atau perilaku, dan elemen struktur pasif. Elemen struktur aktif ini didefinisikan sebagai entity yang mampu melakukan suatu tindakan. Elemen tindakan (behavior) adalah unit aktivitas yang dilakukan oleh satu atau lebih elemen dari struktur aktif. Elemen pasif adalah objek atas tindakan yang dilakukan [6]. Konsep inti Archimate dapat dilihat pada Gambar 2.

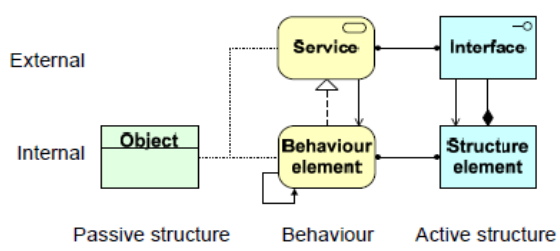

Gambar 2. Konsep inti Archimate [6]

Archimate mendefinisikan konsep yang lebih konkret untuk menspesifikasikan lapisan 
tertentu dari rancangan enterprise architecture. Dalam konteks ini, archimate mempunyai tiga lapisan utama yaitu:

1. Lapisan Bisnis, menawarkan produk dan layanan kepada pelanggan eksternal, yang diwujudkan dalam organisasi oleh proses bisnis (dilakukan oleh pelaku atau peran bisnis).

2. Lapisan Aplikasi, mendukung lapisan bisnis dengan layanan aplikasi yang direalisasikan oleh komponen aplikasi (perangkat lunak).

3. Lapisan Teknologi, menawarkan layanan infrastruktur (misalnya pemrosesan, penyimpanan, dan layanan komunikasi) yang diperlukan untuk menjalankan suatu aplikasi, yang direalisasikan oleh perangkat komputer dan komunikasi serta perangkat lunak sistem.

Di dalam archimate setiap lapisan bisnis, aplikasi dan teknologi terdapat simbol-simbol yang menggambarkan hubungan entitas dan relasi pada enterprise architecture [7]. Pemetaan sederhana pada archimate dapat dilihat pada Gambar 3.

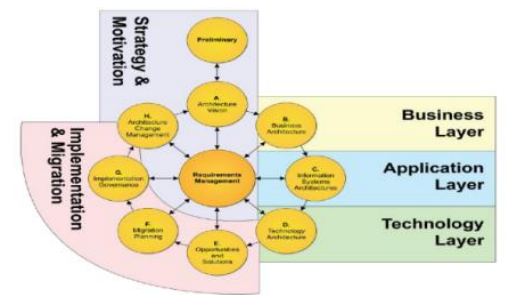

Gambar 3. Pemetaan sederhana antara pemodelan archimate [7]

\subsubsection{Enterprise Architecture Scorecard}

Enterprise architecture scorecard merupakan metodologi dalam mengukur hasil kualitas rancangan enterprise architecture yang dikembangkan oleh Japp Schekkerman. Untuk melakukan pengujjian menggunakan pendekatan enterprise architecture scorecard ini diarahkan untuk mengisi pertanyaan-pertanyaan yang diajukan berupa kuesioner. Penilaian dari setiap butir pertanyaan terdapat ketentuan sebagai berikut:

1. Mengisi nilai 0 apabila tidak tedefinisi dan terdokumentasi dengan baik.

2. Mengisi nilai 1 apabila terdefinisi dan terdokumentasi sebagian

3. Mengisi nilai 2 apabila terdefinisi dan terdokumentasi dengan baik. [8]
Rumus dalam melakukan perhitungan untuk mendapatkan hasil rancangan menggunakan enterprise architecture scorecard seperti pada persamaan nilai 1 .

$$
A=\frac{B}{n \times 2} \times 100 \%
$$

Keterangan:

$\mathrm{A}=$ Nilai hasil perancangan

$\mathrm{B}=$ Total nilai kuesioner

$\mathrm{n}=$ Jumlah pertanyaan kuesioner

Kriteria hasil pengujian berdasarkan nilai dari kuesioner diklasifikasikan sebagai berikut:

1. Jika hasil pengujian $<50 \%$ maka rancangan enteprise architecture dianggap tidak valid

2. Jika hasil pengujian $>50 \%$ maka rancangan enterprise architecture dianggap valid.

\subsubsection{Business Process Modelling Notation (BPMN)}

Business Process Modelling Notation (BPMN) adalah standar de-facto untuk mewakili dengan cara grafis yang pada awalnya diterbitkan pada tahun 2004 oleh Business Process Modelling Initiative sebagai notasi grafis untuk menggambarkan tata letak grafis dari proses bisnis. Tujuan utama BPMN adalah untuk memberikan notasi yang mudah dipahami oleh pengguna bisnis, mulai dari analis bisnis untuk membuat sketsa konsep awal proses bisnis hingga pengembangan teknis yang bertanggung jawab untuk pengimplementasian. [9] BPMN memiliki enam kategori elemen grafis untuk membangun sebuah diagram antara lain:

1. Events, yaitu sesuatu yang terjadi selama proses bisnis. Event mempengaruhi aliran proses dan biasanya memiliki sebab (pemicu) atau dampak (hasil). Event memiliki 3 jenis berdasarkan pengaruh di dalam aliran yaitu start (mulai), intermediate (menengah) dan end (akhir).

2. Gateaways, diwakili oleh bentuk berlian digunakan menentukan keputusan forking, penggabungan, dan penyatuan jalan.

3. Activities, yaitu sebuah aktivitas yang diwakili oleh persegi panjang sudut bulat (lihat gambar di sebelah kanan) dan merupakan istilah umum untuk pekerjaan yang dilakukan perusahaan.

4. Connecting Objects, yaitu sebuah object flow yang dihubungkan bersama dalam diagram untuk membuat struktur kerangka dasar dari proses bisnis. 
5. Swimlanes, digunakan untuk mengatur aspek-aspek proses di dalam BPMN. Swimlanes secara visual mengelompokkan objek menjadi jalur, dengan setiap aspek proses ditambahkan ke jalur yang terpisah. Elemen-elemen ini dapat diatur baik secara horizontal maupun vertikal. Swimlanes tidak hanya mengatur kegiatan ke dalam kategori terpisah, mereka dapat melakukan penundaan, ketidakefisienan, dan pekerja yang bertanggung jawab untuk setiap langkah dalam suatu proses.

6. Artifacts, yaitu sebuah informasi yang relevan dengan model tetapi tidak untuk elemen individu dalam proses. Tiga tipe artefak adalah anotasi, grup, dan objek data yang dapat digunakan dalam diagram BPMN. Ketiganya digunakan untuk menambah dan menjelaskan proses BPMN. [10]

\section{METODE PENELITIAN}

Pada penelitian ini, rancangan usulan metodologi penelitian dengan menggunakan Design Science Research Framework sebagai kerangka panduan dalam menyusun metode penelitian yang akan dilakukan dan menghasilkan output yang sesuai dengan tujuan dan rumusan masalah penelitian. Berikut ini metodologi penelitian dalam perancangan enterprise architecture pada PT. PLN yang dapat dilihat pada Gambar 4.

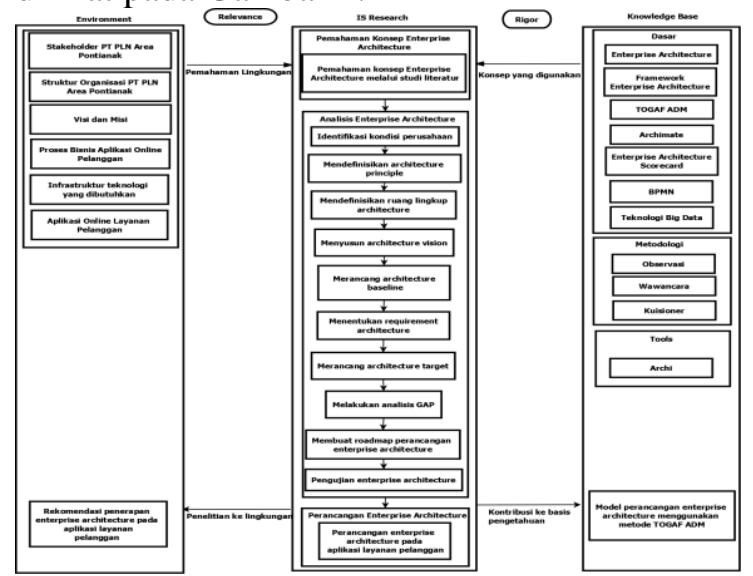

Gambar 4. Kerangka Kerja Penelitian Adapun langkah-langkah dalam penelitian ini antara lain:

1. Pemahaman konsep enterprise architecture melalui studi literatur.
2. Mengidentifikasi kondisi perusahaan pada saat ini untuk mengetahui permasalahan dan aktifitas-aktifitas utama yang ada di perusahaan.

3. Mendefiniskan architecture principle, yaitu mendefiniskan aturan umum yang mendasari dan sebagai pedoman dalam penggunaan enterprise architecture di seluruh bagian perusahaan untuk membentuk suatu dasar dalam pembuatan keputusan TI di masa depan.

4. Mendefinisikan ruang lingkup arsitektur yang mencangkup arsitektur bisnis, arsitektur data \& informasi, arsitektur aplikasi, dan arsitektur teknologi.

5. Menyusun architecture vision, yaitu menentukan visi arsitektur, stakeholder yang terlibat dan strategi bisnis.

6. Merancang architecture baseline untuk menggambarkan kondisi arsitektur pada saat ini untuk mendukung pengembangan target arsitektur.

7. Menentukan requirement architecture, yaitu suatu kondisi atau kemampuan yang harus disesuaikan dalam menciptakan suatu rancangan enterprise architecture untuk mencapai sebuah goal bagi perusahaan.

8. Merancang architecture target untuk menggambarkan target arsitektur yang akan dikembangkan di masa depan.

9. Melakukan analisis gap, yaitu menganalisis perbandingan kondisi saat ini dengan target yang akan diusulkan.

10. Membuat roadmap perancangan enterprise architecture untuk usulan pengembangan enterprise architecture di masa depan.

11. Melakukan pengujian pada rancangan enterprise architecture untuk mengetahui kualitas rancangan yang telah dibuat.

\section{ANALISIS DAN ARSITEKTUR \\ 4.1 Preliminary Phase}

PERANCANGAN

Pada fase ini menggambarkan tahap persiapan dari perencanaan awal dan aktivitasaktivitas dengan mendefinisikan "dimana", "apa", "mengapa", "siapa", dan "bagaimana" melakukan perancangan untuk memenuhi tujuan bisnis dari enterprise architecture. Pada fase ini aspek-aspek utama yaitu mendefinisikan capability perusahaan yang mencangkup 
identifikasi ruang lingkup dan prinsip-prinsip enterprise architecture. Didalam fase ini menghasilkan sebuah artefak yaitu principle catalog yang berisi daftar dari prinsip-prinsip arsitektur bisnis, arsitektur data, arsitektur aplikasi dan arsitektur teknologi berdasarkan dokumen The Open Group yang akan dijadikan dasar dalam perancangan enterprise architecture PT. PLN.

\subsection{Architecture Vision}

Pada fase ini merupakan tahap awal dari perancangan enterprise architecture yang akan dilakukan untuk menjelaskan pentingnya enterprise architecture dalam mencapai tujuan bisnis dari perusahaan. Pada fase ini memetakan visi arsitektur perusahaan dan dan mengidentifikasi stakeholder. Fase ini jug menghasilkan dokumen artefak-artefak berupa stakeholder map matrix, value chain diagram, dan solution concept diagram.

1. Analisis Visi Arsitektur Perusahaan

Visi arsitektur di dalam TOGAF ADM umumnya digunakan pada sebuah perusahaan sebagai acuan dalam menentukan target dari perancangan arsitektur bisnis, arsitektur data, arsitektur aplikasi dan arsitektur teknologi di perusahaan. Analisis visi arsitektur dapat dilihat pada Tabel 2.

Tabel 2. Analisis visi arsitektur dengan prinsip arsitektur pada PT. PLN

\begin{tabular}{|c|l|}
\hline $\begin{array}{c}\text { Prinsip } \\
\text { arsitektur }\end{array}$ & \multicolumn{1}{|c|}{ Visi arsitektur usulan } \\
\hline \multirow{3}{*}{$\begin{array}{c}\text { Business } \\
\text { Architecture }\end{array}$} & $\begin{array}{l}\text { Mengintegrasikan pelayanan pembayaran } \\
\text { listrik ke semua bank. }\end{array}$ \\
\cline { 2 - 2 } & $\begin{array}{l}\text { Memiliki progress dari laporan pengaduan oleh } \\
\text { pelanggan untuk memudahkan pelanggan } \\
\text { dalam mengetahui perkembangan laporan yang } \\
\text { telah diajukan. }\end{array}$ \\
\hline $\begin{array}{c}\text { Business } \\
\text { Architecture \& } \\
\text { Application } \\
\text { Architecture }\end{array}$ & $\begin{array}{l}\text { Mengembangkan fitur virtual account untuk } \\
\text { memudahkan pelanggan dalam melakukan } \\
\text { pembayaran di aplikasi. }\end{array}$ \\
\hline $\begin{array}{c}\text { Data } \\
\text { Architecture }\end{array}$ & $\begin{array}{l}\text { Memiliki big data untuk pengarsipan data, } \\
\text { keamanan data dan analisa data pelanggan pada } \\
\text { aplikasi layanan online pelanggan. }\end{array}$ \\
\hline $\begin{array}{c}\text { Technology } \\
\text { Architecture }\end{array}$ & $\begin{array}{l}\text { Pengembangan jaringan dan server dari aplikasi } \\
\text { layanan online pelanggan. }\end{array}$ \\
\hline
\end{tabular}

\subsection{Business Architecture}

Business architecture merupakan fase pengembangan dari bisnis perusahaan berdasarkan visi arsitektur yang telah dibuat. Tujuan dari fase ini adalah mengembangkan baseline dan target business architecture yang dapat membantu perusahaan mencapai tujuan (goal) serta membuat analisis gap sebagai perbandingan. Artefak-artefak pada perancangan pada business architecture phase untuk aplikasi layanan online pelanggan ini menghasilkan 9 catalog, 4 matrix, dan 11 diagram yang dapat digunakan sebagai acuan pengembangan bisnis layanan online pelanggan.

\section{Goal/Objective/Service Diagram}

Goal/Objective/Service Diagram ini menggambarkan hubungan antara layanan bisnis pada aplikasi layanan online pelanggan PT. PLN dan tujuan dari layanan bisnis itu sendiri dimana dapat berkontribusi untuk mencapai visi atau strategi bisnis perusahaan. Untuk perancangan target pada goal/objective/service diagram ini menambahkan proses bisnis pelacakan pengaduan pada layanan pengaduan listrik beserta tujuan (goal) dari proses pelacakan pengaduan listrik tersebut. Penambahan aktifitas target ini diberi tanda warna hijau dapat dilihat pada Gambar 5.

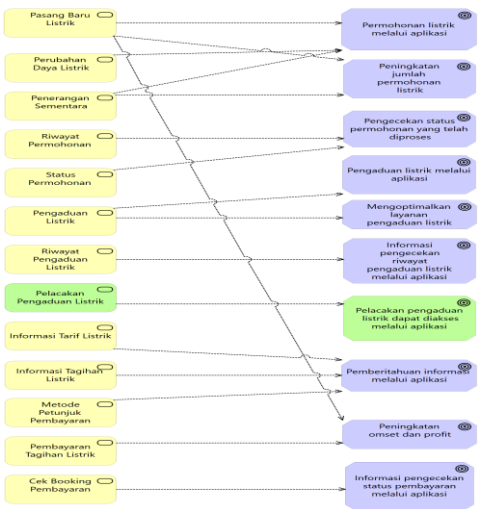

\section{Gambar 5. Goal/Objective/Service Diagram} Target

2. Business Model Diagram

Diagram ini menjelaskan sebuah model bagaimana perusahaan dapat menciptakan, memberikan dan menangkap sebuah nilai bisnis. Untuk menggambarkan business model diagram ini menggunakan pemodelan canvas yang terdiri dari 9 blok komponen canvas dapat dilihat pada Gambar 6.

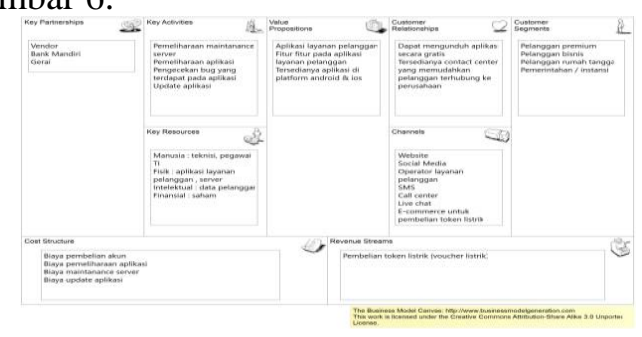

Gambar 6. Business Model Diagram 


\section{Analisis Gap Business Architecture Phase}

Analisis gap merupakan sebuah metode untuk membandingkan kondisi arsitektur baseline dan arsitektur target dari bisnis perusahaan berdasarkan requirement catalog yang telah diidentifikasi pada domain business architecture phase. Pengembangan target dan baseline architecture dari seluruh fungsi bisnis layanan online pelanggan PT. PLN berdasarkan dari hasil analisis yang telah dilakukan dapat dilihat pada Tabel 3.

Tabel 3. Analisis Gap Business Architecture

\begin{tabular}{|c|c|c|c|c|}
\hline Baseline & $\begin{array}{l}\text { Pengelol } \\
\text { aan } \\
\text { Permoh } \\
\text { onan } \\
\text { Listrik }\end{array}$ & $\begin{array}{l}\text { Pengelolaan } \\
\text { Layanan } \\
\text { Pengaduan }\end{array}$ & $\begin{array}{l}\text { Pengelolaa } \\
\mathrm{n} \\
\text { Informasi }\end{array}$ & $\begin{array}{l}\text { Pengelolaan } \\
\text { Pembayaran } \\
\text { Listrik }\end{array}$ \\
\hline $\begin{array}{l}\text { Pengelolaan } \\
\text { Permohonan } \\
\text { Listrik }\end{array}$ & Retain & & & \\
\hline $\begin{array}{l}\text { Pengelolaan } \\
\text { Layanan } \\
\text { Pengaduan }\end{array}$ & & $\begin{array}{l}\text { Dilakukan } \\
\text { penambahan } \\
\text { fitur }\end{array}$ & & \\
\hline $\begin{array}{l}\text { Pengelolaan } \\
\text { Informasi }\end{array}$ & & & Retain & \\
\hline $\begin{array}{l}\text { Pengelolaan } \\
\text { Pembayaran } \\
\text { Listrik }\end{array}$ & & & & $\begin{array}{l}\text { Dilakukan } \\
\text { pengembang } \\
\text { an fitur }\end{array}$ \\
\hline $\begin{array}{l}\text { Keterangan } \\
\text { Target }\end{array}$ & & $\begin{array}{l}\text { Penambahan } \\
\text { fitur tracking } \\
\text { pada layanan } \\
\text { pengaduan } \\
\text { listrik yang } \\
\text { dapat dicek } \\
\text { secara } \\
\text { berkala oleh } \\
\text { pelanggan } \\
\text { melalui } \\
\text { aplikasi PLN } \\
\text { Mobile. }\end{array}$ & & $\begin{array}{l}\text { Pengembang } \\
\text { an layanan } \\
\text { pembayaran } \\
\text { listrik dengan } \\
\text { mengintegras } \\
\text { ikan } \\
\text { pembayaran } \\
\text { listrik ke } \\
\text { seluruh bank }\end{array}$ \\
\hline
\end{tabular}

Keterangan :

$\square=$ Target

Retain $=$ Tidak ada perubahan

\subsection{Data Architecture}

Pada data architecture phase ini mendeskripsikan komponen data sebagai arsitektur baseline untuk pengembangan target data architecture yang mendukung fase sebelumnya yaitu architecture vision phase dan business architecture phase. Pada perancangan didalam fase data architecture ini tidak ada penambahan target arsitektur terkait database di dalam analisis gap karena pada entitas data pelacakan sudah terdapat di dalam aplikasi untuk fitur permohonan dan pembayaran listrik. Data architecture phase ini juga menghasilkan 5 artefak yang berupa catalog, matrix dan diagram.

1. Entity Relationship Diagram
Entity
Relationship
Diagram menggambarkan hubungan diantara relasi entitas data yang mengacu pada aplikasi PLN Mobile. Rancangan entity relationship diagram pada aplikasi layanan online pelanggan PLN Mobile dapat dilihat pada Gambar 7.

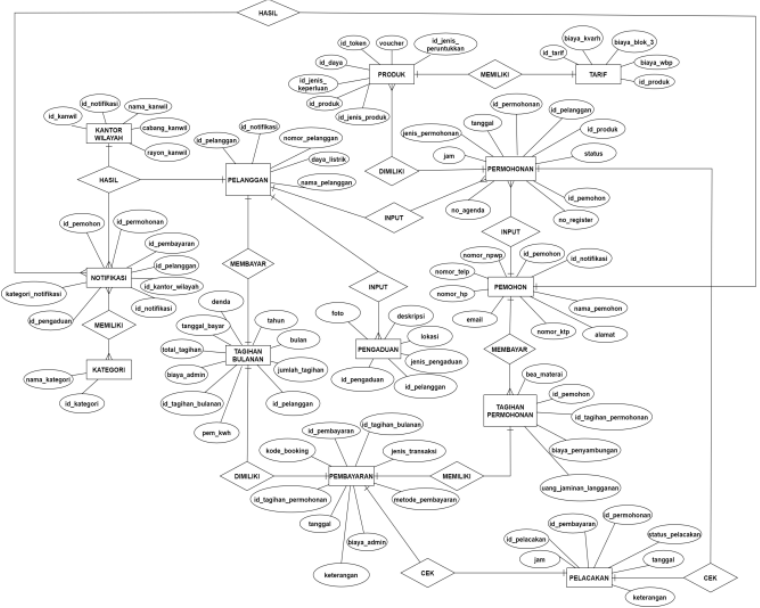

Gambar 7. Entity Relationship Diagram Aplikasi PLN Mobile

\section{Class Diagram}

Di dalam rancangan class diagram pada aplikasi layanan online pelanggan PLN Mobile yang berisi 21 class beserta relasi antara lain Permohonan, Pembayaran, Pengaduan, Pelanggan, Pemohon, Kantor Wilayah, Tagihan Bulanan, Tagihan Permohonan, Notifikasi, Admin, User Sistem, Pelacakan, Produk, Tarif, dan Kategori. Rancangan class diagram pada aplikasi layanan online pelanggan PLN Mobile dapat dilihat pada Gambar 8 .

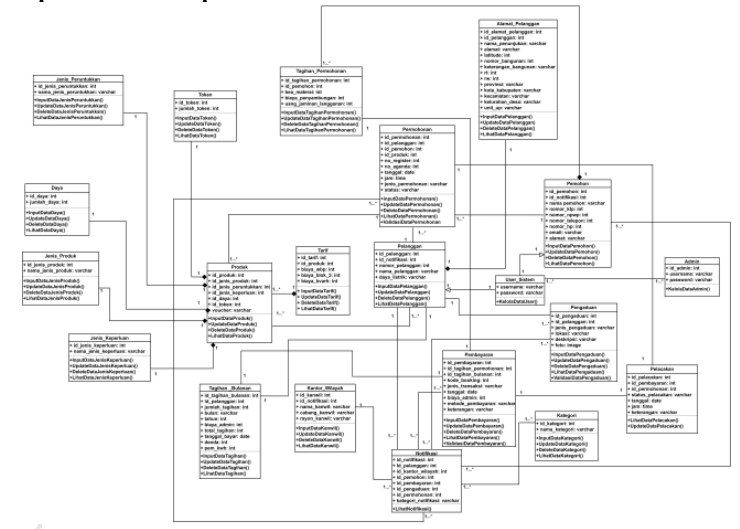

Gambar 8. Class Diagram Aplikasi PLN Mobile 


\subsection{Application Architecture}

Pada fase selanjutnya yaitu application architecture menggambarkan bagaimana sebuah rancangan baseline dan target arsitektur pada domain aplikasi, serta membuat analisis gap sebagai perbandingan. Application Architecture menghasikan 9 artefak yang berupa catalog, matrix dan diagram.

\section{Interface Catalog}

Catalog berikut ini bertujuan untuk mengidentifikasi interface di dalam aplikasi yang berupa komponen aplikasi dan serta hubungannya dengan aplikasi lainnya. Komponen aplikasi PLN Mobile memiliki hubungan dengan komponen aplikasi pendukung lainnya yang dapat dilihat pada Tabel 4.

Tabel 4. Interface Catalog

\begin{tabular}{|c|c|c|}
\hline $\begin{array}{l}\text { Application } \\
\text { Component } \\
\text { PLN Mobile }\end{array}$ & Relationship & $\begin{array}{l}\text { Application } \\
\text { Component }\end{array}$ \\
\hline $\begin{array}{l}\text { Pengelolaan } \\
\text { Permohonan } \\
\text { Listrik }\end{array}$ & $\begin{array}{ll}\text { AP2T : Data id } \\
\text { pelanggan \& } \\
\text { permohonan ubah } \\
\text { daya } & \\
\text { Web PLN : no } \\
\text { agenda, no } \\
\text { registrasi, id } \\
\text { pelanggan, } \\
\text { permohonan } \\
\text { pasang baru dan } \\
\text { permohonan ubah } \\
\text { daya } \\
\end{array}$ & $\begin{array}{l}\text { Aplikasi } \\
\text { Pelayanan } \\
\text { Pelanggan } \\
\text { Terpusat (AP2T), } \\
\text { Web PLN }\end{array}$ \\
\hline $\begin{array}{l}\text { Pengelolaan } \\
\text { Pengaduan } \\
\text { Listrik }\end{array}$ & $\begin{array}{l}\text { Data nomor gangguan } \\
\text { dan status gangguan }\end{array}$ & $\begin{array}{l}\text { Aplikasi } \\
\text { Pengaduan } \\
\text { Keluhan Terpadu } \\
\text { (APKT) }\end{array}$ \\
\hline $\begin{array}{l}\text { Pengelolaan } \\
\text { Informasi }\end{array}$ & - & - \\
\hline $\begin{array}{l}\text { Pengelolaan } \\
\text { Pembayaran } \\
\text { Listrik }\end{array}$ & $\begin{array}{l}\text { Data transaksi } \\
\text { pembayaran listrik }\end{array}$ & $\begin{array}{l}\text { Pengelolaan dan } \\
\text { Pengawasan Arus } \\
\text { Pendapatan Secara } \\
\text { Terpadu } \\
\text { (P2APST) }\end{array}$ \\
\hline
\end{tabular}

\section{Application Communication Diagram}

Diagram ini menggambarkan hubungan seluruh model yang terdapat di dalam aplikasi untuk saling berkomunikasi dan dapat membentuk sebuah sistem yang saling terintegrasi. Untuk perancangan arsitektur target pada application communication diagram dengan menambahkan komponen aplikasi pelacakan pengaduan listrik di dalam fungsi pengaduan listrik yang ditandai dengan warna hijau. Perancangan target application communication diagram dapat dilihat pada Gambar 9.

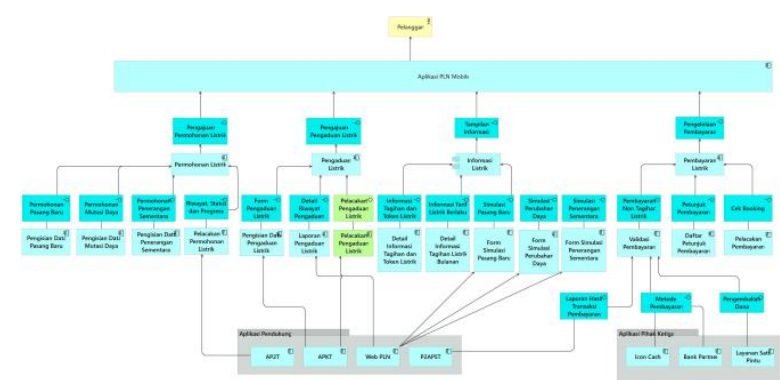

Gambar 9. Application Communication Diagram Target Aplikasi PLN Mobile

3. Analisis Gap Application Architecture

Analisis gap digunakan untuk membandingkan kondisi arsitektur baseline dan arsitektur target dari aplikasi perusahaan berdasarkan requirement catalog yang telah diidentifikasi dapat dilihat pada Tabel 5.

Tabel 5. Analisis Gap Application Architecture

\begin{tabular}{|c|c|c|c|c|}
\hline $\begin{array}{l}\text { Target } \\
\text { Baselin } \\
\text { e }\end{array}$ & $\begin{array}{l}\text { Kompone } \\
\mathrm{n} \\
\text { Aplikasi } \\
\text { Permoho } \\
\text { nan } \\
\text { Listrik }\end{array}$ & $\begin{array}{l}\text { Komponen } \\
\text { Aplikasi } \\
\text { Layanan } \\
\text { Pengaduan }\end{array}$ & $\begin{array}{l}\text { Kompo } \\
\text { nen } \\
\text { Aplikas } \\
\text { i } \\
\text { Informa } \\
\text { si }\end{array}$ & $\begin{array}{l}\text { Komponen } \\
\text { Aplikasi } \\
\text { Pembayaran } \\
\text { Listrik }\end{array}$ \\
\hline $\begin{array}{l}\text { Kompo } \\
\text { nen } \\
\text { Aplikas } \\
\text { i } \\
\text { Permoh } \\
\text { onan } \\
\text { Listrik }\end{array}$ & Retain & & & \\
\hline $\begin{array}{l}\text { Kompo } \\
\text { nen } \\
\text { Aplikas } \\
\mathrm{i} \\
\text { Layana } \\
\mathrm{n} \\
\text { Pengad } \\
\text { uan }\end{array}$ & & $\begin{array}{l}\text { Dilakukan } \\
\text { penambah } \\
\text { an } \\
\text { komponen } \\
\text { aplikasi }\end{array}$ & & \\
\hline $\begin{array}{l}\text { Kompo } \\
\text { nen } \\
\text { Aplikas } \\
\mathrm{i} \\
\text { Inform } \\
\text { asi }\end{array}$ & & & Retain & \\
\hline $\begin{array}{l}\text { Kompo } \\
\text { nen } \\
\text { Aplikas } \\
\text { i } \\
\text { Pemba } \\
\text { yaran } \\
\text { Listrik }\end{array}$ & & & & $\begin{array}{l}\text { Dilakukan } \\
\text { penambahan } \\
\text { komponen } \\
\text { aplikasi }\end{array}$ \\
\hline $\begin{array}{l}\text { Ketera } \\
\text { ngan } \\
\text { Target }\end{array}$ & & $\begin{array}{l}\text { Penambah } \\
\text { an } \\
\text { komponen } \\
\text { aplikasi } \\
\text { tracking } \\
\text { pengaduan } \\
\text { listrik } \\
\text { yang dapat } \\
\text { dilacak } \\
\text { oleh } \\
\end{array}$ & & $\begin{array}{l}\text { Penambahan } \\
\text { komponen } \\
\text { aplikasi virtual } \\
\text { account pada } \\
\text { aktivitas } \\
\text { bayar pada } \\
\text { fungsi } \\
\text { pembayaran } \\
\text { listrik }\end{array}$ \\
\hline
\end{tabular}


Tabel 5. Analisis Gap Application Architecture

\begin{tabular}{|c|c|c|c|c|}
\hline $\begin{array}{l}\text { Target } \\
\text { Baselin } \\
\mathrm{e}\end{array}$ & $\begin{array}{l}\text { Kompone } \\
\text { n } \\
\text { Aplikasi } \\
\text { Permoho } \\
\text { nan } \\
\text { Listrik }\end{array}$ & $\begin{array}{l}\text { Komponen } \\
\text { Aplikasi } \\
\text { Layanan } \\
\text { Pengaduan }\end{array}$ & $\begin{array}{l}\text { Kompone } \\
\mathrm{n} \\
\text { Aplikasi } \\
\text { Informasi }\end{array}$ & $\begin{array}{l}\text { Komponen } \\
\text { Aplikasi } \\
\text { Pembayaran } \\
\text { Listrik }\end{array}$ \\
\hline $\begin{array}{l}\text { Ketera } \\
\text { ngan } \\
\text { Target }\end{array}$ & & $\begin{array}{l}\text { pelanggan } \\
\text { melalui } \\
\text { aplikasi } \\
\text { PLN } \\
\text { Mobile. }\end{array}$ & & \\
\hline
\end{tabular}

Keterangan :

$\square=$ Target

Retain $=$ Tidak ada perubahan

\subsection{Technology Architecture}

Pada fase technology architecture ini mendeskripsikan hubungan antara komponen aplikasi dengan komponen teknologi yang mendukung baik komponen perangkat lunak (software) maupun komponen perangkat keras (hardware) untuk mendukung integrasi bisnis yang diperlukan serta membuat analisis gap sebagai perbandingan. Fase technology architecture ini menghasilkan 5 artefak yang berupa catalog, matrix dan diagram.

1. Technology Standard Catalog

Technology Standards Catalog ini mendefinisikan mengenai standar teknologi yang digunakan pada PT. PLN Unit Induk Wilayah Kalimantan Barat. Untuk perancangan target pada Technology Standards Catalog ditandai dengan warna orange dapat dilihat pada Tabel 6 .

Tabel 6. Technology Standards Catalog Target PT. PLN Unit Induk Wilayah Kalimantan Barat

\begin{tabular}{|l|l|l|}
\hline No. & \multicolumn{1}{|c|}{ Technology } & \multicolumn{1}{c|}{ Standar } \\
\hline 1. & $\begin{array}{l}\text { Operating } \\
\text { System (OS) }\end{array}$ & $\begin{array}{l}\text { Operating System } \\
\text { Client: Windows 10 } \\
\text { Server: Windows Server }\end{array}$ \\
\hline 2. & Database & $\begin{array}{l}\text { Database } \\
\text { Terpusat: Oracle } \\
\text { Lokal: MySQL }\end{array}$ \\
\hline 3. & $\begin{array}{l}\text { Jaringan } \\
\text { (Network) }\end{array}$ & $\begin{array}{l}\text { Peralatan Network } \\
\text { Switch: CISCO, Dell } \\
\text { Router: CISCO, Microtic } \\
\text { Koneksi Network } \\
\text { Kantor Wilayah: LAN } \\
\text { Kantor Unit Pelangggan: VPN IP } \\
\text { Network } \\
\text { Koneksi Aplikasi: Internet \& } \\
\text { Intranet }\end{array}$ \\
\hline 4. & $\begin{array}{l}\text { Provider } \\
\text { ICON+ } \\
\text { Telkom }\end{array}$ \\
\hline
\end{tabular}

Tabel 6. Technology Standards Catalog Target PT. PLN Unit Induk Wilayah Kalimantan Barat (Lanjutan)

\begin{tabular}{|l|l|l|}
\hline No. & Technology & \multicolumn{1}{c|}{ Standar } \\
\hline 4. & $\begin{array}{l}\text { Provider } \\
\text { Jaringan }\end{array}$ & Progressio \\
\hline 5. & $\begin{array}{l}\text { Payment } \\
\text { Technology }\end{array}$ & $\begin{array}{l}\text { Payment Technology } \\
\text { Transfer via ATM Bank } \\
\text { Icon Cash } \\
\text { Virtual Account }\end{array}$ \\
\hline 6. & $\begin{array}{l}\text { Keamanan } \\
\text { Sistem }\end{array}$ & $\begin{array}{l}\text { Keamanan Sistem } \\
\text { Firewall: Sophos } \\
\text { Antivirus: Kaspersky }\end{array}$ \\
\hline 7. & $\begin{array}{l}\text { Business } \\
\text { Intellegent } \\
\text { BI) }\end{array}$ & $\begin{array}{l}\text { Business Intellegent } \\
\text { Big Data }\end{array}$ \\
\hline
\end{tabular}

Keterangan :

\section{$\square=$ Target}

2. Network and Communication Diagram

Diagram ini menggambarkan komunikasi diantara seluruh aset teknologi di dalam arsitektur teknologi. Untuk perancangan target pada network and communication diagram ini menambahkan teknologi cloud computing untuk rancangan big data pada jaringan aplikasi pusat dan lokal yang terhubung seperti pada gambar berikut ini. Teknologi cloud computing untuk rancangan big data menggunakan Amazon Web Service (AWS). Network and communication diagram dapat dilihat pada Gambar 10.

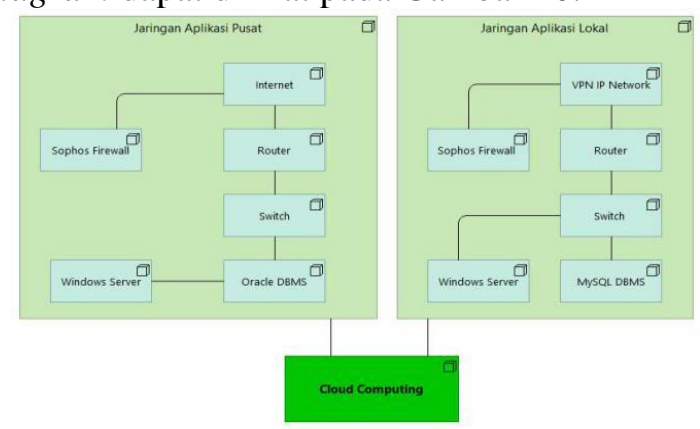

Gambar 10. Network and Communication Diagram Target pada Aplikasi Layanan Online Pelanggan

3. Analisis Gap Technology Architecture Phase

Analisis gap merupakan sebuah metode untuk membandingkan kondisi arsitektur baseline dan arsitektur target dari teknologi perusahaan berdasarkan requirement catalog yang telah diidentifikasi pada domain technology architecture phase. Analisis gap pada technology architecture phase dapat dilihat pada Tabel 7. 
Tabel 7. Analisis Gap Technology Architecture

\begin{tabular}{|l|l|l|l|l|l|l|l|}
\hline B & OS & D & N & P & PT & KS & BI \\
\hline OS & $\begin{array}{c}\text { Ret } \\
\text { ain }\end{array}$ & & & & & & \\
\hline $\mathbf{D}$ & & $\begin{array}{c}\text { Retai } \\
\mathrm{n}\end{array}$ & & & & & \\
\hline $\mathbf{N}$ & & & $\begin{array}{c}\text { Reta } \\
\text { in }\end{array}$ & & & & \\
\hline $\mathbf{P}$ & & & & $\begin{array}{c}\text { Retai } \\
\mathrm{n}\end{array}$ & & & \\
\hline $\mathbf{P T}$ & & & & & Add & & \\
\hline KS & & & & & & $\begin{array}{c}\text { Retai } \\
\mathrm{n}\end{array}$ & \\
\hline BI & & & & & & & Add \\
\hline $\begin{array}{l}\text { Kete } \\
\text { rang } \\
\text { an }\end{array}$ & & & & & $\begin{array}{c}\text { Peng } \\
\text { guna } \\
\text { an } \\
\text { VA }\end{array}$ & & $\begin{array}{c}\text { Peng } \\
\text { guna } \\
\text { an } \\
\text { Big } \\
\text { Data }\end{array}$ \\
\hline
\end{tabular}

Keterangan:

$\mathrm{T}=$ Target

$\mathrm{B}=$ Baseline

$\mathrm{OS}=$ Operation System

$\mathrm{D}=$ Database

$\mathrm{N}=$ Network

$\mathrm{P}=$ Provider

$\mathrm{PT}=$ Payment Technology

$\mathrm{KS}=$ Keamanan Sistem

$\mathrm{VA}=$ Virtual Account

Retain $=$ Tidak ada perubahan

$\square=$ Target

\subsection{Opportunities and Solution}

Pada fase ini dilakukan evaluasi domain business architecture sampai dengan technology architecture berdasarkan dengan analisis gap dari masing-masing domain. Artefak-artefak yang dihasilkan pada fase ini antara lain Gap Konsolidasi, Project Context Diagram dan Benefit Diagram.

\section{Project Context Diagram}

Diagram ini menunjukkan ruang lingkup yang akan diimplementasikan sebagai project pengembangan enterprise architecture yang menghubungkan bagian stakeholder, requirement, fungsi bisnis, proses bisnis, komponen aplikasi dan aplikasi eksternal yang berpengaruh di dalam project tersebut. Project Context Diagram dapat dilihat pada Gambar 10.

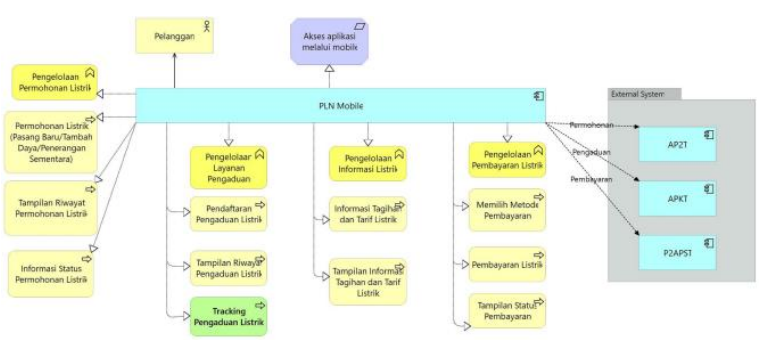

Gambar 11. Project Context Diagram Target PLN Mobile

\section{Benefit Diagram}

Benefit diagram ini menggambarkan hubungan dari objective, solution, outcome dan measurement dari usulan pengembangan enterprise architecture kemudian menghasilkan sebuah benefit / manfaat yang didapatkan oleh perusahaan. Benefit diagram dapat dilihat pada Gambar 11.

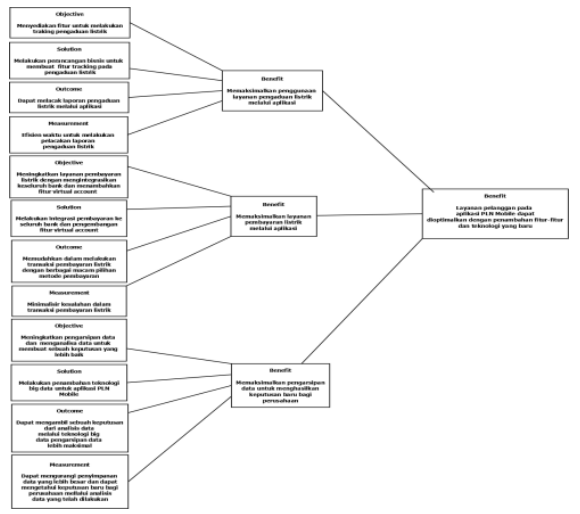

Gambar 12. Benefit Diagram PT. PLN

\subsection{Migration Planning}

Pada fase ini terdapat teknik-teknik yang digunakan untuk mendukung perencanaan migration planning dari pengembangan enterprise architecture baseline dan target yang telah diidentifikasi. Di dalam migration planning phase ini menghasilkan artefak antara lain Implementation Factor Assesment and Deduction Matrix dan Consolidate Gaps, Solutions and Dependencies Matrix.

1. Implementation Factor Assesment and

Deduction Matrix

Pada matrix ini digunakan untuk mendokumentasikan faktor-faktor yang mempengaruhi rencana implementasi dan rencana migrasi. Faktor-faktor yang mempengaruhi antara lain risk (resiko), issues (permasalahan), dependencies (ketergantungan), action (tindakan), dan impact (dampak). 
Implementation Factor Assesment and Deduction Matrix PLN Mobile dapat dilihat pada Tabel 8.

Tabel 8. Implementation Factor Assesment and

\begin{tabular}{|c|c|c|c|}
\hline \multicolumn{4}{|c|}{ Deduction Matrix PLN Mobile } \\
\hline $\begin{array}{c}\text { Fact } \\
\text { or } \\
\text { Type }\end{array}$ & Factor & Deskripsi & Deduction \\
\hline \multirow{2}{*}{ Risk } & $\begin{array}{l}\text { Gangguan } \\
\text { koneksi } \\
\text { intenet dan } \\
\text { server }\end{array}$ & $\begin{array}{l}\text { Koneksi internet dan } \\
\text { server terkadang } \\
\text { tidak stabil }\end{array}$ & $\begin{array}{l}\text { Menghambat } \\
\text { proses bisnis yang } \\
\text { dilakukan di } \\
\text { dalam aplikasi }\end{array}$ \\
\hline & $\begin{array}{l}\text { Kerusakan } \\
\text { hardware }\end{array}$ & $\begin{array}{l}\text { Kerusakan hardware } \\
\text { yang disebabkan } \\
\text { oleh human error } \\
\text { maupun bencana }\end{array}$ & $\begin{array}{lr}\text { Kerugian pada } \\
\text { perusahaan dan } \\
\text { menghambat } \\
\text { proses bisnis }\end{array}$ \\
\hline $\begin{array}{l}\text { Issue } \\
\text { s }\end{array}$ & $\begin{array}{l}\text { Pengemban } \\
\text { gan layanan } \\
\text { pelanggan } \\
\text { dan } \\
\text { teknologi } \\
\text { informasi } \\
\text { pada } \\
\text { perusahaan }\end{array}$ & $\begin{array}{l}\text { Dilakukan } \\
\text { pengembangan } \\
\text { layanan pelanggan } \\
\text { dan teknologi } \\
\text { informasi } \\
\text { perusahaan untuk } \\
\text { mendukung kinerja } \\
\text { dan mencapai tujuan } \\
\text { bisnis perusahaan }\end{array}$ & $\begin{array}{l}\text { Adanya } \\
\text { perencanaan } \\
\text { pengembangan } \\
\text { layanan pelanggan } \\
\text { dan teknologi } \\
\text { informasi } \\
\text { perusahaan } \\
\text { berdasarkan hasil } \\
\text { analisis yang telah } \\
\text { dilakukan } \\
\text { sebelumnya }\end{array}$ \\
\hline $\begin{array}{l}\text { Depe } \\
\text { nden } \\
\text { cies }\end{array}$ & $\begin{array}{l}\text { Keterkaitan } \\
\text { antara } \\
\text { bisnis, data, } \\
\text { teknologi } \\
\text { dan aplikasi } \\
\text { pada } \\
\text { perusahaan }\end{array}$ & $\begin{array}{l}\text { Keterkaitan antara } \\
\text { proses bisnis aplikasi } \\
\text { PLN Mobile dengan } \\
\text { aset teknologi dan } \\
\text { data yang ada di } \\
\text { perusahaan. }\end{array}$ & $\begin{array}{lr}\text { Kesesuaian proses } \\
\text { bisnis, rata, } \\
\text { aplikasi r dan } \\
\text { teknologi dengan } \\
\text { kondisi eksisting } \\
\text { dan rajuan } \\
\text { perusahan }\end{array}$ \\
\hline $\begin{array}{c}\text { Actio } \\
n\end{array}$ & $\begin{array}{l}\text { Perekapan } \\
\text { data yang } \\
\text { terotomasi }\end{array}$ & $\begin{array}{l}\text { Perekapan data } \\
\text { terkait pelanggan } \\
\text { dan perusahaan } \\
\text { sudah menggunakan } \\
\text { database terotomasi }\end{array}$ & $\begin{array}{l}\text { Penggunaan } \\
\text { database oracle } \\
\text { dan mysql untuk } \\
\text { perekapan dan } \\
\text { penyimpanan data }\end{array}$ \\
\hline $\begin{array}{c}\text { Impa } \\
c t\end{array}$ & $\begin{array}{l}\text { Adanya } \\
\text { penambaha } \\
\mathrm{n} \text { fitur } \\
\text { pelacakan } \\
\text { pengaduan } \\
\text { listrik dan } \\
\text { big data } \\
\text { untuk } \\
\text { mendukung } \\
\text { pengolahan } \\
\text { data yang } \\
\text { baik }\end{array}$ & $\begin{array}{l}\text { Penambahan fitur } \\
\text { pelacakan } \\
\text { digunakan untuk } \\
\text { pengambilan } \\
\text { keputusan saat } \\
\text { terjadi kesalahan } \\
\text { pada laporan } \\
\text { pengaduan listtrik. } \\
\text { Penambahan big } \\
\text { data digunakan } \\
\text { untuk penyimpanan } \\
\text { data yang lebih } \\
\text { besar dan } \\
\text { pengambilan } \\
\text { keputusan untuk } \\
\text { perusahaan } \\
\text { berdasarkan analisa } \\
\text { data yang ada }\end{array}$ & $\begin{array}{l}\text { Peningkatan } \\
\text { layanan pelanggan } \\
\text { pada perusahaan }\end{array}$ \\
\hline
\end{tabular}

\section{IMPLEMENTASI DAN PENGUJIAN ENTERPRISE ARCHITECTURE}

\subsection{IT Roadmap}

IT Roadmap merupakan usulan dari perancangan target enterprise architecture yang telah dibuat sebelumnya. Pembuatan IT Roadmap mengacu pada rancangan target pada fase Business Architecture, Application Architecture dan Technology Architecture dengan estimasi rentang waktu 3 tahun. IT Roadmap dapat dilihat pada Tabel 9.

\begin{tabular}{|c|c|c|}
\hline $\begin{array}{l}\text { Phase, } \\
\text { Tahun }\end{array}$ & 2020 & 2022 \\
\hline \multirow{2}{*}{$\begin{array}{l}\text { Business } \\
\text { Architec } \\
\text { ture } \\
\text { Phase }\end{array}$} & \multicolumn{2}{|c|}{$\begin{array}{l}\text { Penambahan fitur pelacakan } \\
\text { pada layanan pengaduan } \\
\text { listrik di aplikasi }\end{array}$} \\
\hline & \multicolumn{2}{|c|}{$\begin{array}{l}\text { Integrasi pembayaran listrik } \\
\text { keselırıh hank }\end{array}$} \\
\hline $\begin{array}{c}\text { Applicati } \\
\text { on } \\
\text { Architec } \\
\text { ture } \\
\text { Phase }\end{array}$ & & $\begin{array}{l}\text { Penambahan komponen aplikasi } \\
\text { pelacakan pengaduan listrik dan } \\
\text { virtual account di aplikasi }\end{array}$ \\
\hline \multirow{2}{*}{$\begin{array}{c}\text { Technol } \\
\text { ogy } \\
\text { Architec } \\
\text { ture } \\
\text { Phase }\end{array}$} & & $\begin{array}{l}\text { Pengembangan teknologi virtual } \\
\text { account untuk pembayaran }\end{array}$ \\
\hline & \multicolumn{2}{|c|}{ Pengembangan teknologi big data } \\
\hline
\end{tabular}

\subsection{Pengujian Enterprise Architecture}

Pada pengujian enterprise architecture ini menggunakan metode enterprise architecture scorecard dengan memberikan kuesioner yang berisi 22 pertanyaan yang diberikan kepada 2 responden yaitu manager operasional STI PLN Kalbar dan asisten manager operasional STI PLN Kalbar. Berikut ini butir pertanyaan dan hasil kuisioner dari 2 responden PLN Kalbar.

Dari hasil pengisian kuesioner, responden mengisi tiap butir pertanyaan dengan ketentuan penilaian:

1. Mengisi nilai 0 apabila tidak terdokumentasi, terdefinisi dan tertulis dengan baik.

2. Mengisi nilai 1 apabila sebagian terdokumentasi, terdefinisi dan tertulis.

3. Mengisi nilai 2 apabila terdokumentasi, terdefinisi dan tertulis keseluruhan.

Berdasarkan ketentuan penilaian tersebut di dapatkan hasil dengan menggunakan rumus enterprise architecture scorecard dapat dilihat pada Tabel 10.

Tabel 10. Hasil Perhitungan Kuesioner

\begin{tabular}{|c|c|c|c|c|c|}
\hline No & $\begin{array}{c}\text { Business } \\
\text { Architect } \\
\text { ure }\end{array}$ & $\begin{array}{c}\text { Data } \\
\text { Architect } \\
\text { ure }\end{array}$ & $\begin{array}{c}\text { Applicati } \\
\text { on } \\
\text { Architect } \\
\text { ure }\end{array}$ & $\begin{array}{c}\text { Technolo } \\
\text { gy } \\
\text { Architect } \\
\text { ure }\end{array}$ & $\begin{array}{c}\text { Rata- } \\
\text { Rata }\end{array}$ \\
\hline 1 & $65,9 \%$ & $65,9 \%$ & $63,63 \%$ & $63,63 \%$ & $\begin{array}{c}64,76 \\
\%\end{array}$ \\
\hline 2 & $61,36 \%$ & $61,36 \%$ & $61,36 \%$ & $63,63 \%$ & $\begin{array}{c}61,92 \\
\%\end{array}$ \\
\hline \multicolumn{5}{|c|}{ Total nilai rata-rata: } & $\begin{array}{c}63,34 \\
\%\end{array}$ \\
\hline
\end{tabular}


Sehingga nilai rata-rata dari 2 responden adalah $63,34 \%$ dapat dinyatakan hasil perancangan enterprise architecture valid diatas $50 \%$. Maka secara keseluruhan rancangan baseline dan target architecture PLN dinyatakan valid.

\section{PENUTUP \\ 6.1 Kesimpulan}

Berikut ini kesimpulan dari penelitian yang telah dilakukan antara lain:

1. Berdasarkan hasil perancangan enterprise architecture pada aplikasi layanan online pelanggan PLN, menghasilkan rancangan baseline dan target arsitektur yang berupa catalog, matrix dan diagram. Adapun hasil perancangan target arsitektur pada business architecture phase hingga technology architecture phase antara lain:

a. Pada Business Architecture Phase dari hasil analisis baseline sebelumnya dilakukan penambahan fitur tracking pada layanan pengaduan listrik dan pengembangan layanan pembayaran listrik dengan mengintegrasikan pembayaran keseluruh bank.

b. Pada Data Architecture Phase tidak ada penambahan rancangan target enterprise architecture.

c. Pada Appplication Architecture Phase dilakukan penambahan komponen aplikasi tracking pengaduan listrik dan penambahan komponen aplikasi virtual account pada aktivitas bayar pada fungsi pembayaran listrik di aplikasi.

d. Pada Technology Architecture Phase dilakukan penambahan teknologi virtual account untuk memudahkan dalam pembayaran listrik melalui aplikasi dan penambahan teknologi big data.

2. Berdasarkan hasil pengujian enterprise architecture yang telah dilakukan melalui pengisian kuesioner didapatkan nilai ratarata dari 2 responden adalah 63,34\%. Dapat dinyatakan perancangan enterprise architecture pada aplikasi layanan online PT. PLN valid.

\subsection{Saran}

Berdasarkan penelitian yang telah dilakukan, terdapat beberapa saran yang dapat ditulis untuk perancangan enterprise architecture aplikasi layanan online pelanggan PLN Unit Induk Wilayah Kalimantan Barat antara lain:

1. Hasil penelitian ini dapat digunakan sebagai acuan dalam melakukan pengembangan TI yang selaras dengan proses bisnis perusahaan.

2. Penelitian ini hanya terbatas sampai Migration Planning Phase, diharapkan untuk penelitian selanjutnya dapat dilakukan sampai phase berikutnya di dalam TOGAF ADM.

\section{DAFTAR PUSTAKA}

[1] Kustiyahningsih, Y. 2013. Perencanaan Arsitektur Enterprise Menggunakan Metode TOGAF ADM. Prosiding Seminar Nasional Manajemen Teknologi XVIII, 18.

[2] The Open Group. 2018. The TOGAF Standard, Version 9.2.

[3] Miftahuddin, Y., Ichwan, M., \& Musrini, M. 2013. Penerapan Metode EAP (Enterprise Architecture Planning) Pada Pembuatan Blueprint Sistem Akademik. Jurnal Informatika, 4(1), 39-47.

[4] Yunis, R., \& Surendro, K. (2009). Perancangan Model Enterprise Architecture Dengan TOGAF. Seminar Nasional Aplikasi Teknologi Informasi.

[5] Lusa, S., \& Sensuse, D. I. 2011. Kajian Perkembangan dan Usulan Perancangan Enterprise Architecture Framework. Seminar Nasional Aplikasi Teknologi Informasi, 17-18.

[6] Berrisford, G., \& Lankhorst, M. 2009. Using ArchiMate with TOGAF Part 1: Answers to nine general questions about methods. (June), 1-9.

[7] Josey, A., Lankhorst, M., Band, I., Jonkers, H., \& Quartel, D. 2016. An Introduction to the Archimate 3.0 Specification.

[8] Schekkerman, J. 2004. Enterprise Architecture Score Card. Institute For Enterprise Architecture Development.

[9] Chinosi, M., \& Trombetta, A. (2012). BPMN: An introduction to the standard. Computer Standards \& Interfaces, 124134.

[10] White, S. A. (2004). Introduction to BPMN. BPTrends IBM Corporation, 1-11. 